\title{
Distribution Profile of Extended Spectrum Beta Lactamase (ESBL) Producing Escherichia coli Isolates from Asa River (Nigeria)
}

\section{*11OLATUNJI, MATTHEW KOLAWOLE; ALBERT, OLAYEMI; FAUSAT, JIMOH}

\author{
${ }^{I}$ Infectious Diseases and Environmental Health Research Group, \\ Department of Microbiology, University of Ilorin, P.M.B. 1515, Ilorin, Nigeria. \\ ${ }^{2}$ Infectious Diseases and Environmental Health Research Group, Microbiology Unit, \\ Department of Biosciences and Biotechnology, College of Pure and Applied Sciences, Kwara State \\ University, Malete, P.M.B. 1530, Nigeria. \\ *Corresponding author: Dr. O.M. Kolawole; email:tomak7475@gmail.com
}

\begin{abstract}
Escherichia coli are known pathogenic organism that has caused diseases which has led to severe morbidity and increased death rate. The occurrence of extended spectrum beta Lactamase (bla) producing Escherichia coli has been on the rise. Water samples were investigated as a potential reservoir for the Extended Spectrum BetaLactamase (ESBL) - producing E. coli using phenotypic (culture-based) and molecular methods. Double disc synergy test was determined between a disc of amoxicillin-clavulanate $(20 \mu \mathrm{g} / 10 \mu \mathrm{g})$ (augmentin) and a 30- $\mu \mathrm{g}$ disc of each thirdgeneration cephalosporin antibiotic placed at a distance of $20 \mathrm{~mm}$ from centre to centre on a Mueller-Hinton Agar plate streaked with the isolate. An isolate was considered to be ESBL negative if there was no enhancement between any of the cephalosporin and the clavulanate-containing discs and were then subjected to specific Polymerase Chain Reaction (PCR). Eighty-four environmental E. coli was isolated. 58(69.04\%) showed positivity for ESBL production. E. coli isolates positive for ESBL-production selected and subjected to plasmid curing were all plasmid mediated. 16 isolates subjected to PCR to identify the presence of blaSHV (Sulphydryl Variable), blaTEM (Temoneira) and blaCTX-M (Cefotaximase) genes revealed that $11(68.7 \%)$ of these had at least one ESBL gene (either blaCTX-M or blaTEM, or both), 5(31.3\%) isolates do not have any of the three ESBL genes, and blaSHV was not detected in any of the isolates. The results of this study indicate the widespread prevalence of ESBLs in E. coli. Therefore, beta-lactam antibiotics and beta-lactamase inhibitors should be prescribed based on an antibacterial susceptibility test. @ JASEM
\end{abstract}

\section{http://dx.doi.org/10.4314/jasem.v20i4.9}

\section{Keywords: WATER, E. coli, ESBL, DDST, PLASMID CURING and ASA RIVER}

The spread of genes coding for extended-spectrum beta-lactamases (ESBLs) among Enterobacteriaceae is alarming globally and is of significant public health concern (NORM, 2010). It is thought that over one billion people are colonized with ESBL-producing Enterobacteriaceae intestinally. The major agents of the propagation of these strains are misuse and over usage of antibiotics in humans and animals and circulation of antibiotic residues and ESBL in the environment (Zhang et al., 2015; Canton et al., 2012; Tenaillon et al., 2010). Patients with infections caused by ESBL are known to suffer from increased incidence of diseases and death rate compared to patients with infections caused by non-ESBLproducing Enterobacteriaceae (Rottier et al., 2012).

Extended-spectrum beta-lactamase-producing Enterobacteriaceae can be disseminated in humans through contaminated food or water (Zhang et al., 2015) and capable of inactivating extended-spectrum cephalosporin. They can be inhibited by extended spectrum $\beta$-lactamase inhibitors, such as clavulanic acid via plasmid-encoded or chromosomonallyencoded $\beta$-lactamases. Water environments are considered as one of the major reservoirs for resistance genes (Zhang et al., 2015), and possibly play a significant role in transfer of drug-resistant genes between bacteria (Malakoff, 2002; Kummerer, 2004).

Escherichia coli is the most widespread pathogenic organism among Enterobacteriaceae in human diseases and causes serious and common infections such as septicemia and urinary tract infection (UTI) (NORM, 2010). It is also the most commonly occurring ESBL-producing enterobacteriaceae, which are inhabitants of gastrointestinal tract and important pathogens in nosocomial and in the environment (Song et al., 2011; Tenaillon et al., 2010).

To date in Nigeria, there are numerous studies on ESBL-producing Enterobacteriaceae from clinical isolates. However, information on ESBL-producing Enterobacteriaceae isolated from waters from rivers is very limited. The global occurrence of antibiotic resistance of $E$. coli in water is of increasing concern; this informed the need to assess the impact of pollution on Asa river segments and evaluate the effectiveness of augmentation of clavulanate with Cefotaxime, Ceftazidime, Aztreonam and Ceftriaxone in detecting ESBL production in the $E$. coli isolates. This study aimed at investigating the prevalence of genes coding for ESBL-production in $E$. coli isolated from Asa River in Ilorin, Nigeria.

\section{MATERIALS AND METHODS}

Study Area and Water Sampling: Water sampling was carried out at weekly intervals for a period of 8 weeks on Asa River in Ilorin, Nigeria. The study was conducted on 5 different Asa River segments; Amilegbe road, Station road, Unity road, Offa-garage road and Asa dam. The samples were collected into pre-sterilized bottles kept on ice and transported 
immediately to the laboratory for analyses within 2 hours.

Isolation and Identification: Isolates were recovered from the water samples after incubation on Eosin Methylene Blue Agar and MacConkey Agar, for 1824 hours at $37^{\circ} \mathrm{C}$. Presumptive characteristic E. coli isolates were identified and confirmed using IMViC tests while potential ESBL producers were identified based on manufacturers' instructions (Oxoid Ltd, England).

Double Disc Synergy Test / DDST: The double disc detection test was done by determining the synergy between a disc of amoxicillin-clavulanate (AMC30) and a $30-\mu \mathrm{g}$ disc of each third-generation cephalosporin test antibiotic placed at a distance of 20 $\mathrm{mm}$ from centre to centre on a Mueller-Hinton Agar (MHA) plate inoculated with the test isolate. Clear extension of the edge of the inhibition zone of cephalosporin toward the amoxicillin-clavulanate disc was interpreted as positive for ESBL production (Bradford et al., 1997) while no enhancement between any of the cephalosporins and the clavunatecontaining discs was regarded as negative.

Plasmid Curing: The ESBL positive isolates were subjected to acridine orange (Merck) mediated plasmid elimination using the method of Stanisich and were also re-tested for ESBL production using DDST (Iroha et al., 2010).

Isolation of genomic DNA of ESBL E. Coli and Detection of resistance gene using PCR method: Pure cultures were grown overnight in Nutrient broth and genomic DNA was extracted using the Cetyl Trimethyl Ammonium Bromide (CTAB) extraction procedure (Devi et al., 2013).

In order to detect genes encoding Ambler class A beta-lactamases (bla), standard PCR was performed with genomic DNA as a template. For amplification of genes encoding SHV beta-lactamases $\left(b l a_{\mathrm{SHV}}\right)$, primers SHV-F (5'GACAGTTACCAATGCTTAATCA3') and SHVR (5'TCGGGCCGCGTAGGCATGAT 3') were used (Mojtaba and Behnaz, 2012). Reaction conditions used were $94^{\circ} \mathrm{C}$ for $300 \mathrm{~s}$, followed by 36 cycles of denaturation $\left(94^{\circ} \mathrm{C} ; 60 \mathrm{~s}\right)$, annealing $\left(39.5^{\circ} \mathrm{C} ; 30 \mathrm{~s}\right)$ and extension $\left(72^{\circ} \mathrm{C} ; 120 \mathrm{~s}\right)$, and a final extension at $72^{\circ} \mathrm{C}$ for $240 \mathrm{~s}$.

For amplification of genes encoding TEM betalactamases $\left(b l a_{\mathrm{TEM}}\right), \quad$ primers TEM-F (5'ATAAAATTCTTGAAGACGAAA 3' ) and TEMR (5'GACAGTTACCAATGCTTAATCA3') were used with thermal cycling conditions of $94^{\circ} \mathrm{C}$ for 300 $\mathrm{s}$, followed by 36 cycles of denaturation $\left(94^{\circ} \mathrm{C} ; 60 \mathrm{~s}\right)$, annealing $\left(42.9^{\circ} \mathrm{C} ; 30 \mathrm{~s}\right)$, extension $\left(72^{\circ} \mathrm{C} ; 120 \mathrm{~s}\right)$, and a final extension at $72^{\circ} \mathrm{C}$ for $240 \mathrm{~s}$. In order to detect genes for CTX-M beta-lactamases $\left(b l a_{\mathrm{CTX}-\mathrm{M}}\right)$, primers CTX-MU1

(5'TTAATGATGACTCAGAGCATTC 3') and CTXMU2 (5'GATACCTCGCTCCATTTATTG3') were used and the thermal cycling condition as described above except annealing $\left(49.2^{\circ} \mathrm{C} ; 30 \mathrm{~s}\right)$.

The PCR product stained with ethidium bromide was electrophorese in a $1.7 \%(\mathrm{w} / \mathrm{v})$ agarose gel for $1 \mathrm{hr}$ at $140 \mathrm{~V}$ together with High Ranger $1 \mathrm{~kb}$ and PCR Sizer 100bp DNA ladder (NORGEN) and visualized under UV illumination.

\section{RESULTS AND DISCUSSION}

Eighty- four isolated E. coli were selected for phenotypic testing while 58(69.04\%) showed positivity for ESBL. Table 1 shows The Percentage Resistance Pattern of the Isolates on the Various Beta Lactam Antibiotic Discs.

The results of the plasmid curing with acridine orange revealed that all the ESBL positive E. coli could not express the ESBL enzyme after their incubation with $0.1 \mathrm{mg} / \mathrm{ml}$ acridine orange.

Figure 1 shows 16 of the 58 ESBL positive isolates that were subjected to PCR for the presence of blaSHV, bla $a_{\mathrm{TEM}}$ and blaCTX-M genes. 11(68.7\%) of these had at least one ESBL gene (either blaCTX-M or blaTEM, or both), 5(31.3\%) isolates didn't have any of the three ESBL genes, and blaSHV was not detected in any of the isolates (Figures 2-4).

Escherichia coli is a known pathogenic organism that has caused severe nosocomial, urinary tract infection, blood borne disease and gastroenteritis which has led to severe morbidity and increased death rate. Following the wide consumption and constant abuse of the extended spectrum beta lactam agent, the outbreaks of infection caused by extended spectrum $\beta$-lactamase producing $E$. coli have been widely reported throughout the world (Branger et al.,1998). The production of ESBLs is a major threat to the use of new generation of cephalosporins (Putman et al., 2000; Mendes et al., 2004). Long hospitalization, diabetes, age over 60 and antibiotic treatment have been reported previously as the risk factors to acquire infections with ESBL strains (Silva et al., 2006).

The present results showed that, out of the 84 E. coli isolates screened for $\beta$ - lactamase production using third-generation Cephalosporins (Cefotaxime, Ceftriaxone and Ceftazidime) and monobactam (Aztreonam); 58(69.04\%) showed positivity for ESBL production. Previous studies reported that, 
primary antimicrobial susceptibility test of E. coli isolates observed high resistance to third-generation Cephalosporins such as Cefotaxime, Ceftriaxone and Ceftazidime. Some studies also show resistance to $\beta$ lactam antibiotics (especially third-generation Cephalosporins) and non- $\beta$ - lactam antibiotics, amongst which clinical isolates of gram-negative bacteria are increasing worldwide (Goossens, 2000; Andrew, 2001) and this correlates with the present research.

In this study, Ceftriaxone detected $28.6 \%$ of the ESBL producers at a distance of $20 \mathrm{~mm}$. This was followed by Cefotaxime at $26.2 \%$, Ceftazidime at $23.8 \%$ and Aztreonam at $21.4 \%$ in the presence of Amoxicillin- clavulanic acid. It was observed that this study is in contrast to the work of Babypadmini and Appalara, (2004).

The effect of plasmid curing studies in this study shows that the plasmid resistant maker of positive ESBL isolates was eliminated which means that the ESBL genes of these isolates (E. coli) are plasmidmediated. The percentage of isolates expressing ESBL production is variable in relation to previous reports of ESBL occurrence from Nigeria with respect to the chromosomal and extra-chromosomal location of the resistance determinants. On the other hand, Enabulele and Uraih (2009) reported that, the resistance by gram negative wound isolates was plasmid-mediated. Hence this study correlates with the study of Enabulele and Uraih (2009).

However, in a later study, Yah et al., (2007) and Iroha et al., (2009) reported their findings that the production of ESBL can be chromosomal or plasmid in origin. When these are considered in relation to this present finding they seem to be in contrary. The ESBLs can either be carried on chromosomes or plasmids and plasmid-mediated ESBLs can carry genes that have the ability to transfer a replica of themselves to other bacteria. The transferable plasmids also code for resistant determinants to other antimicrobial agents, hence, multidrug resistance is anticipated to be commonest among ESBLproducing organisms. ESBLs that are chromosomal in origin cannot easily be transferred from organism to organism (Iroha et al., 2009).

The most ESBLs in this study were CTX-type and TEM-type enzymes while failed to detect SHV-type in isolated E. coli. $68.8 \%$ of these had at least one ESBL gene (either blaCTX-M or blaTEM, or both), $5(31.3 \%)$ isolates didn't have any of the three ESBL genes. The results in this study showed prevalence of CTX-type and SHV-type to be $68.7 \%$ and $25.0 \%$ respectively.

In a similar report, the most abundant ESBL gene was bla $a_{\text {СтХ-м, }}$ the second-most prevalent gene was $b l a_{\mathrm{TEM}}$ and the $b l a_{\mathrm{SHV}}$ gene was not found (SuYing et al., 2010). It has also been reported by Iroha et al., (2009) that, blaSHV gene could not be found in any of their isolates. The above studies correlate with the present finding while Mojtaba and Behnaz, (2011) failed to detect CTX-M type ESBL in the isolated strains which is in contrary to this research. The variation in this study results compared with others about prevalence rate of ESBLs may be due to different reasons such as difference in type and volume of consumption of antibiotics and difference in time which the isolates were collected (Al-Agamy et al., 2009).

In epidemiological studies, the $b a_{\text {CTX-M }}$ gene has been widespread in clinical settings globally (Coque et al., 2008), but it has seldom been identified in environmental isolates. Recently, Reinthaler et al. reported that the $b l a_{\text {СтХ-м }}$ gene was dominant in ESBL-producing bacteria isolated from Austrian sewage sludge, with the $b l a_{\mathrm{TEM}}$ gene as the secondmost prevalent type (Reinthaler et al., 2010). The present research was in concordance with the above study, but the latter data indicated that the CTX-Mtype ESBL- gene had already been prevalent in a river sediment environment.

The $b l a_{\text {СтХ-м }}$ group is unique among ESBL genes. CTX-M was initially identified in 1989 and its pandemic (CTX-M) has changed the prevalence of ESBLs, and it has rapidly become the dominant ESBL worldwide (Canton and Coque, 2006). Previous reports suggest that the CTX-Ms had several different environmental origins, in contrast to TEM and SHV, with single ancestors (Barlow et al., 2008). CTX-M not only is associated with nosocomial outbreaks but is also mostly found in communityacquired infections. The high degree of diversity of $b l a_{\text {CTX-M }}$ genes in this present study, in the river could have two potential origins: the hospital effluent or naturally occurring strains. This result indicates that novel $b l a_{\text {СтX-м }}$ genes could be identified from the environment and that the river environment could be a potential reservoir of novel ESBL genes that may pose a potential risk to public health.

Table 1: The Percentage Resistance Pattern of the Isolates on the Various Beta Lactam Antibiotic Discs

\begin{tabular}{lll}
\hline Antibiotic disc & Inhibition zone & No of isolates $(\%)$ \\
\hline Ceftriaxone & $\leq 25 \mathrm{~mm}$ & $24(28.60)$ \\
Cefotaxime & $\leq 27 \mathrm{~mm}$ & $22(26.20)$ \\
Ceftazidime & $\leq 22 \mathrm{~mm}$ & $20(23.80)$ \\
Aztreonam & $\leq 27 \mathrm{~mm}$ & $18(21.40)$ \\
\hline
\end{tabular}




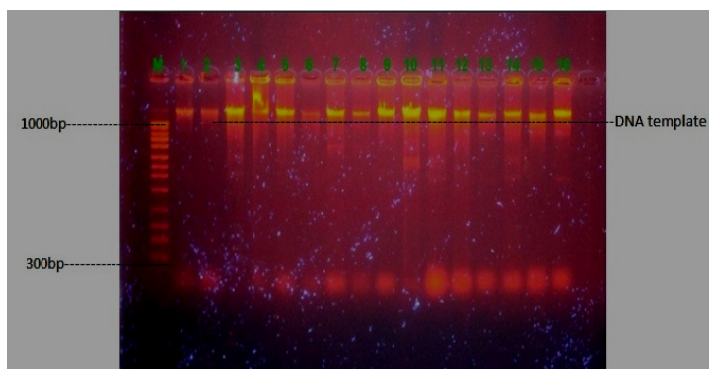

Fig 1: E.coli genomic DNA.M:1kb DNA marker; NC: negative control; Lanes 1-16: E. coli isolates genomic DNA template.

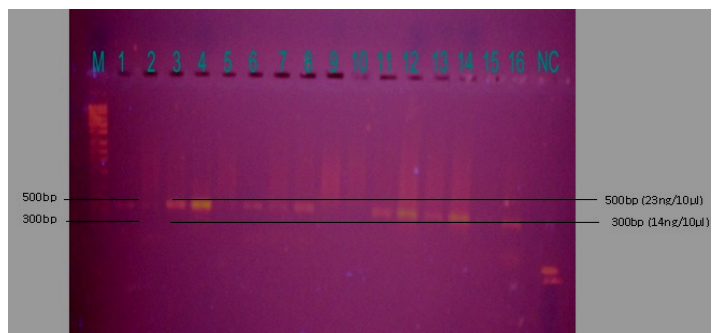

Fig 2: blaCTX-M gene PCR amplicon. M: $1 \mathrm{~kb}$ DNA marker; NC: negative control; lanes 1-16: E. coli isolates positive for the blaCTX-M gene.

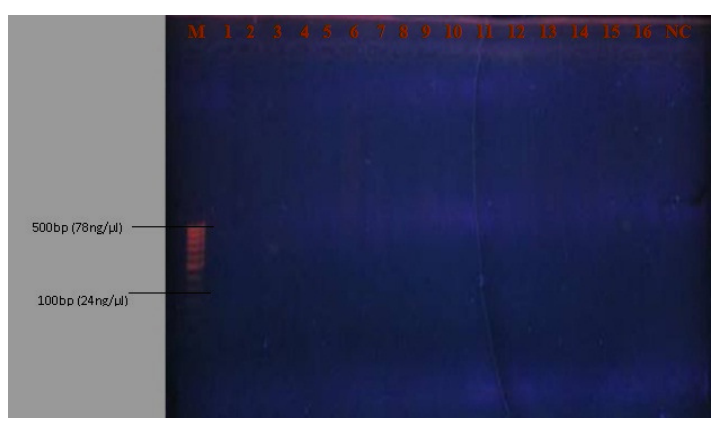

Fig 3: blaSHV gene PCR amplicon. M: 100 bp DNA marker; NC: negative control; lanes 1-16: E. coli isolates negative for the blaSHVgene.

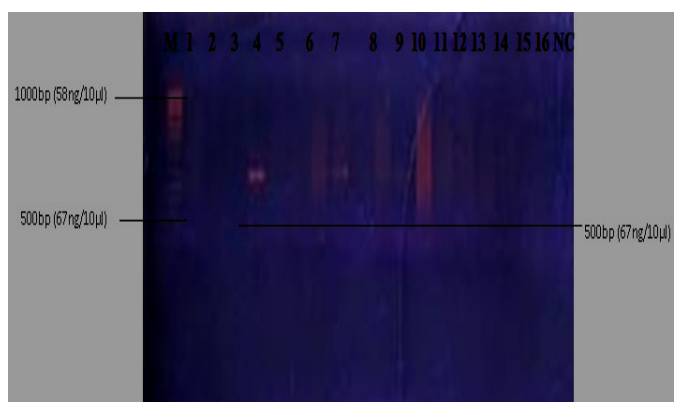

Fig 4: blaTEM gene PCR amplicon. M: 1kb DNA marker;

NC: negative control; lanes 1-16: E. coli isolates positive for the blaTEM gene.
Conclusion: There is apparently high prevalence of ESBL producing strains of $E$. coli in present study environment and the enzyme genes are plasmid mediated. The high prevalence of $E$. coli that showed resistance to Beta lactam antibiotics in the studied river in Kwara State call for a serious concern as this river serve as a source of livelihood for the people living in the environment. The outcome of this study has demonstrated the palpable presence of ESBL producing bacteria strains from community within Ilorin metropolis to the best of our knowledge. This kind of study remains relevant towards providing adequate baseline for the future projection and effective management of infectious diseases caused by the ESBL producing bacteria strains.

Acknowledgements: We wish to acknowledge $\mathrm{Mr}$ Ogah I.J and Mr Suleiman M.M for their assistance.

\section{REFERENCES}

Al-Agamy, MHM; Shibl, AM; Tawfik, AF (2009). Prevalence and molecular characterization of extended-spectrum $\quad \beta$-lactamase-producing Klebsiella pneumoniae in Riyadh, Saudi Arabia. Annual Saudi Medical report 29: 253-257.

Andrew, JM (2001). BSAC working party on susceptibility testing method. J Antimicrob Chemother 48: 43-57.

Babypadmini, S; Appalara, SB (2004). Extended Spectrum B-Lactamases in Urinary Isolates of Escherichia coli and Klebsiella pneumoniae Prevalence and Susceptibility Pattern in a Tertiary Care Hospital, Indian. J Med Microbiol 22:172-174.

Barlow, M; Reik, RA; Jacobs, SD; Medina, M; Meyer, MP; McGowan, JE Jr; Tenover, FC (2008). High rate of mobilization for blaCTXMs. Emergence of Infectious Diseases. 14: 423428.

Bradford, PA; Urban, C; Mariano, N; Projan, SJ; Rahal, JJ; Bush, K (1997). Imipenem resistance in Klebsiella pneumoniae is associated with the combination of ACT-1, a plasmid-mediated AmpC $\beta$-lactamase, and the loss of an outer membrane protein. Antimicrob Agents Chemother 41: 563-569.

Branger, C; Lesimple, AL; Bruneu, B; Berry, P; Lambert-Zechovsky, N (1998). Long-term investigation of the clonal dissemination of Klebsiella pneumoniae isolates producing extended-spectrum $\beta$-lactamases in a university hospital. J Med Microbiol 47: 210-209. 
Canton, R; Gonzalez-Alba, JM; Galan, JC (2012). CTX-M enzymes: origin and diffusion. Front Microbiol 3: 110

Canton, R; Coque, TM (2006). The CTX-M $\beta$ lactamase pandemic. Curr Opin Microbiol 9:466475.

Coque, TM; Baquero, F; Canton, R (2008). Increasing prevalence of ESBL-producing Enterobacteriaceae in Europe, Euro Surveill 13

Devi, KD; Punyarani,K; Singh, NS; Devi,HS (2013). An efficient protocol for total DNA extraction from the members of order Zingiberales- suitable for diverse PCR based downstream applications. SpringerPlus. 2(669): 1186

Enabulele, SA; Uraih, N (2009). Enterohaemorrhagic Escherichia coli 0157:H7 Prevalence in meat and vegetables sold in Benin City, Nigeria. Afri J Microbiol Res 3(5): 276-279.

Iroha, IR; Adikwumu, E; Aibinu, I; Amadis, ES (2009). Extended spectrum beta lactamase (ESBL) in E. coli isolated from tertiary hospital in Enugu state, Nigeria. Pakistan J Med Sci 25: 279-282.

Iroha, IR; Amadi, ES; Oji, AE ; Nwuzo, AC; EjikeUgwu, PC (2010). Detection of Plasmid Borne Extended Spectrum Beta Lactamase Enzymes from Blood and Urine Isolates of Gram-Negative Bacteria from a University Teaching Hospital in Nigeria. Current Res Bacteriol 3: 77-83.

Goossens, H (2000). MYSTIC (Meropenem Yearly Susceptibility Test Information Collection) results from Europe: comparison of antibiotic susceptibility between countries and center types. J Antimicrob Chemother 46:39- 52.

Kummerer, K (2004). Resistance in the environment. J Antimicrob Chemother 54: 311-320.

Malakoff, D (2002). Microbiologists on the trail of polluting bacteria. Science 29: 2352-2353.

Mendes, C; Kiffer, C; Segura, A; Ribeiro, J; Turner, P (2004). Klebsiella pneumoniae with multiple antimicrobial resistances, Brazillian. J Infect Dis 8:109-111.

Mojtaba, M; Behnaz, D (2012). Distribution of TEM, SHV and CTX-M Genes among ESBLproducing Enterobacteriaceae isolates in Iran. Afri J Microbiol Res. 6(26): 5433-5439.
NORM/NORM-VET. (2010) Usage of antimicrobial agents and occurrence of antimicrobial resistance in Norway. Troms $\emptyset$, Oslo; 1502-2307.

Putman, M; VanVeen, HW; Konings, WN (2000). Molecular properties of bacterial multidrug transporters. Microbial Molecular Biological Review 64:672-693.

Reinthaler, FF; Feierl, G; Galler, H; Haas, D; Leitner, E; Mascher, F; Melkes, A; Posch, J; Winter, I; Zarfel, G; Marth, E. (2010). ESBL-producing E. coli in Austrian sewage sludge. Water Res 44(6):1981-1985.

Rottier, WC; Ammerlaan, HS; Bonten, MJ (2012). Effects of confounders and intermediates on the association of bacteraemia caused by extendedspectrum beta-lactamase-producing Enterobacteriaceae and patient outcome: a metaanalysis. J Antimicrob Chemother 67: 1311-20

Silva, N; Oliveira, M; Bandeira, AC; Brites, C (2006). Risk factors for infection by extended spectrum-spectrum beta-lactamase producing Klebsiella pneumoniae in a tertiary hospital in Salvador, Brazil. Brazillian J Infect Dis 10: 191193

Song, JH; Thamlikitkul, V; Hsueh, PR (2011). Clinical and economic burden of communityacquired pneumonia amongst adults in the AsiaPacific region. Int J Antimicrob Agents 38:108117.

Tenaillon, O; Skurnik, D; Picard, B; Denamur, E (2010). The population genetics of commensal Escherichia coli. Nat Rev Microbiol 8: 207-17

Yah, SC; Eghafona, NO; Oranusi, S; Abouo, AM (2007). Widespread plasmid resistance genes among Proteus species in diabetic wounds of patients in the Ahmadu Bello University Teaching Hospital (ABUTH) Zaria. Afri J Biotechnol 6: 1757-1762.

Zhang, H; Zhou, Guo, Y; Chang, W (2015). Multidrug resistance found in extended-spectrum beta-lactamase-producing Enterobacteriaceae from rural water reservoirs in Guantao, China. Front Microbiol 6: 267 